\title{
INTUITION IN DECISION-MAKING: REVIEW, MAP OF INFLUENTIAL RESEARCHERS, AND RESEARCH AGENDA
}

\begin{abstract}
RESUMO
Objetivo: Identificar os grupos informais de redes, a estrutura e a evolução longitudinal da história intelectual da intuição na tomada de decisão nos últimos 52 anos. Método: Métodos mistos foram usados, análise de redes sociais de 887 artigos, juntamente com a revisão sistemática da literatura e análise de conteúdo das principais publicações. Principais Resultados: Os resultados indicam duas correntes teóricas que estavam implícitas na literatura: pesquisadores que entendem a intuição relacionada à experiência e seguem a abordagem padrão-intervencionista e pesquisadores que entendem a importância dos elementos sensoriais, afetivos, juntamente com a experiência; e seguem a abordagem competitivaparalela. Um fluxo com os marcos da intuição na tomada de decisão é apresentado dividido em quatro etapas: construção do conceito, validação, aplicação empírica e estudos emergentes. Contribuições: Este estudo contribui teoricamente, oferecendo uma revisão da temática diferente do que os outros estudos encontraram, por meio da apresentação de um mapa de pesquisadores influentes, seus seguidores, posicionamento teórico e metodológico dos autores e agenda de pesquisa para estudos futuros. Também oferece contribuições práticas ao apresentar o tema de forma estruturada, os gestores e empreendedores podem refletir sobre suas práticas e analisar se tem usado (e como) intuição na tomada de decisão. Também pode estimular reflexões e aplicação de ferramentas no ensino e treinamento sobre a temática. Originalidade: Este é o primeiro estudo a aplicar a técnica de redes sociais e a análise do caminho principal para entender a intuição, o que permitiu alguns avanços no conhecimento sobre a temática, demostrado nos resultados e contribuições.
\end{abstract}

Palavras-chave: Correntes teóricas. Mapa de autores. Análise do caminho principal. Análise de redes sociais. Análise de co-citação. Análise de citação.

\begin{abstract}
Objective: To identify the informal groups of networks, the structure, and the longitudinal evolution of the intellectual history of intuition in decision-making in the last 52 years. Method: We use mixed methods such as social networks of 887 articles together with the systematic review and content analysis of the leading publications. Main Results: The results indicate two theoretical currents: researchers who understand intuition related to the experience and follow the default-interventionist approach and researchers understand the importance of sensory, affective elements, together with the experience. They follow the parallel-competitive approach. We indicate a flow with the milestones of intuition in decisionmaking divided into four stages: concept construction, validation, empirical application, and emerging studies. Contributions: This study contributes theoretically, offering a review, a map of influential researchers, their followers, theoretical positioning of the authors through the academic and methodological basis, and research agenda. It provides practical contributions by presenting the topic in a structured way, as managers and entrepreneurs can reflect on their practices and analyze how they have used their intuition. It can also encourage application in teaching and training tools. Originality: This is the first study to apply social networks and main path analysis to understand intuition.
\end{abstract}

Keywords: Theoretical currents. Map of authors. Analysis of the main path. Analysis of social networks. Co-citation analysis. Citation analysis.

\section{INTRODUCTION}

Informal groups of networks, or 'invisible faculties', form the research field's intellectual production. They are composed of scholars who identify with common research problems and rely on the explanation of the phenomenon by citing previous studies, also as a way to document this history (Burt, 1977). Researchers who participate in this network develop concepts or discoveries that are tested, absorbed, and improved by the community and advance to form scientific knowledge (Culnan, 1986). It is relevant because it can provide the understanding and intellectual evolution of academics from different disciplines. This is the first study to use network analysis to identify the informal groups of 
networks, the structure, and the evolution of the main advances in the intellectual history of intuition in decision-making in the last 52 years (1968-2019). Thus, which until now, this has been implicit in studies (Hodgkinson \& Sadler-Smith, 2018).

Beyond the quality and speed of decisions, some authors have related intuition to wise decisionmaking (Intezari \& Pauleen, 2017). It can positively affect organizational performance (Hough \& Ogilvie, 2005; Kaufmann et al., 2014; Sadler-Smith, 2004; Taggart \& Valenzi, 1990), being more suited to unstable and strategic-level environments, in opposition to operational decisions (Dane \& Pratt, 2009; Eling et al., 2015; Intezari \& Pauleen, 2017; Kaufmann et al., 2014; Khatri \& Ng, 2000). It can also assist in the growth of companies (Allinson et al., 2000; Dutta \& Thornhill, 2008).

Recognizing its relevance and its application in management, prestigious academic conferences, such as the Academy of Management Proceedings, started in 2009 an exclusive symposium to discuss the intuition that still happens today. From the 1930s, intuition has attracted the attention of researchers (Akinci \& Sadler-Smith, 2012; Sadler-Smith, 2019) from various areas of business, entrepreneurship, management, and psychology (Baldacchino et al., 2015).

Over time, different authors have carried out systematic review studies and offered significant advances and contributions to the knowledge of intuition in decision-making. How did these authors contribute? How do their jobs differ from what we propose here? To answer these questions, first, we identified the literature review studies on intuition to understand what they did, to identify research opportunities, and how our study can theoretically contribute. From that, we found that some authors focused on specific aspects and other studies revised intuition in general.

Some studies carried out a literature review on intuition, historically and systematically. However, the authors focused on more specific aspects: types of intuition (Dörfler \& Ackermann, 2012; Reynolds, 2006; Salas et al., 2010; Sonenshein, 2007; Weaver et al., 2014), skills in management (Claxton et al., 2015; Harvey \& Novicevic, 2002; McKenzie et al., 2009); intuition in management education (Burke \& Sadler-Smith, 2006; Sadler-Smith \& Shefy, 2007), balance between intuition and analysis (Okoli \& Watt, 2018; Reynolds, 2006), intuition in group decision-making (Davis, 1992), and limitations of intuition (Miller \& Ireland, 2005).

Other authors studied intuition in a more general way. Dane and Pratt (2007) reconceptualize intuition as "affectively charged judgments that arise through rapid, nonconscious, and holistic associations". They also developed a model and propositions that incorporate domain knowledge, implicit and explicit learning, and task characteristics on intuition effectiveness. Carter et al. (2017) reconceptualize the intuition in decision-making in the supply chain as "a multidimensional construct that consists of dimensions based on experience, emotional and automatic". Baldacchino et al. (2015) did a systematic review based on 25 articles that studied intuition in the field of entrepreneurship. They indicated the main themes studied, published journals, theories used as support, antecedents, and results of intuition, and different research directions. Akinci and Sadler-Smith (2012) understood the progress of intuition in management over the past eight decades and identified guidelines for future studies. They discussed the difference between intuition research in management and intuition research in basic disciplines and related areas. Finally, the authors critically analyzed how these segments affected the progress of the study on the subject.

These studies have offered contributions, but different from our proposal. It is first time identifying informal groups of networks in the research of intuition in decision-making. It is relevant because it provides a theoretical understanding of an interdisciplinary view. Other authors have also proposed to conduct studies of social networks in different areas and have offered various contributions (Georgiou, 2014; Rossetto et al., 2018; Silva et al., 2019). We conducted a mixed-method through a social network together with systematic literature review and the content analysis.

This study contributes theoretically, since, being the first study to use different techniques, it offers a deep understanding of intuition in decision-making, a review of the main contributions of previous studies, and the identification of 'invisible faculties.' It also offers a map of the researchers who influence studies on the subject, their followers, and the main theoretical bases. Additionally, through the analysis of the main path, we indicate the 15 articles to be read, as well as the reading order (not necessarily chronological) for a general understanding of the main advances in the theme. This study also offers practical contributions, as managers and entrepreneurs understand the theoretical evolution of intuition in decision-making, make contact with the topic in a structured way. They can 
reflect on their practices and analyze the extent to which they have used their intuition. It can also assist and encourage the application of the theme in teaching and training tools.

\section{LITERATURE REVIEW}

The decision-making literature in organizations has mostly focused on the fact that managers are comprehensive, rational, and analytical (Elsbach \& Barr, 1999). In this perspective, many studies adopted the classic decision approach - Rational Choice Theory, in which decision-making is the result of linear thoughts and the consequence of a conscious will or choice (Etzioni, 1992; Janis \& Mann, 1977; Zelikow \& Allison, 1999). (Elsbach \& Barr, 1999; Weick \& Leite, 1973). "Rationality is socially constructed every day through interactions and is used to legitimize what happened" (Weick \& Leite, 1973, p. 9).

Simon $(1955,1956)$ contested some of the rational choice theory (a view of 'homo economicus' that defines the human being with rationality that seeks to maximize decisions and results through the optimal choice among the available alternatives). The author proposed Bounded Rationality Theory, which states that the brain has limitations to process a large number of options and information to be explored, as well as the market's uncertainties, dynamism, and time pressure. Both approaches recognize the decision-making process as linear. There is a conception of a path to be followed with a beginning, middle, and end. They also understand that the problem precedes the solution.

Other authors follow a different line of research based on the non-linear decision-making process. Cohen et al. (1972) presented the Garbage Can Model in an attempt to explain that over time we accumulate different solutions and, at some point, recover according to the problem to be solved. Posteriorly, Behn (1988) suggests Groping Along Theory, which he considers that, in organizational decision-making, actions are prioritized, groping the possibilities to achieve the defined objectives. Lastly, through the theoretical approach Sensemaking, Weick (1995) proposes that people are guided by solutions that make sense to them. Thus, he recognizes the importance of the experiences built up over time.

Volatility, uncertainty, complexity, and ambiguity (VUCA) are characteristics of the contemporary scenario. In some cases, there is a restriction of historical data due to the new situations and, in other cases, a significant volume of information to be interpreted quickly (Robinson et al., 2017). In light of this, different authors have sought to understand aspects that can optimize decision-making.

Increasing complexity and dynamism in organizations' environments makes the role of intuition increasingly remarkably more critical in strategic decision-making (Calabretta et al., 2017; Elbanna \& Fadol, 2016; Keller \& Sadler-Smith, 2019; Khatri \& Ng, 2000; Robinson et al., 2017). This cognitive process can help in the speed and effectiveness of decision-making (Dane \& Pratt, 2007; Eling et al., 2015; Khatri \& Ng, 2000). It can be the only approach available depending on the scenario (Elbanna, 2006).

Over the years, different authors have focused on theoretical studies to define the concepts. Sinclair and Ashkanasy (2005) define intuition as a non-sequential process involving cognition and affect, arising from direct knowledge and without the use of conscious reasoning. For Dane and Pratt (2007, p. 36), intuitions as "affectively charged judgments that arise through rapid, nonconscious, and holistic associations." Sadler-Smith (2016b, p. 12) defined it as "positively- or negatively-valenced affective states, manifesting cognitively or somatically, arising automatically, rapidly and subconsciously, informed by prior learning and experiences, affording subjective evaluations and guiding subsequent behaviors" in decision-making, problem-solving, and creativity. Although there are different definitions in the literature, (Calabretta et al., 2017) indicate points in common between studies recognizing intuition as it happens unconsciously and quickly (compared to rational thinking) through holistic associations and recognition of patterns connected to long-term memory. The decision-maker makes a mental simulation of the implementation of a given script before acting and is usually accompanied by affection or emotions. Additionally, studies indicate different ways to manage intuition in decision-making (Bakken et al., 2017; Calabretta et al., 2017; Keller \& Sadler-Smith, 2019; Okoli \& Watt, 2018; Sadler-Smith \& Hodgkinson, 2016; Sayegh et al., 2004; Sinclair et al., 2010).

The Cognitive-Experiential Self-Theory (CEST) explains the intuition in the process of choice in decision-making. The processing of personal information happens through dual systems, the intuitive (unconscious, fast, associative, automatic) and the analytical rational (conscious, slow, deliberate), these 
work in parallel, are interactive and complementary, being that the combined influences people's behavior (Epstein, 1990).

\section{METHODS}

We used mixed methods (social networks together with systematic literature review and the content analysis) to identify the informal groups of networks, the structure, and the longitudinal evolution of the intellectual history of intuition in decision-making in the last 52 years. Social network analysis provides a visual analysis of the relationship between individuals and their connection to a group. Thus, it allows the understanding of the types of social relations, seeking to follow and understand patterns. Furthermore, it helps to understand questions such as: Who are the most influential authors, connectors, and subject matter experts? How do they crowd together? Which authors belong to the network? Who is part of the core? (De Nooy et al., 2018; Zhao \& Strotmann, 2015).

We analyzed co-citation authors and citation documents (Van Eck \& Waltman, 2010; Zhao \& Strotmann, 2015), both use article references (Garfield et al., 1983). "Co-citation is the frequency with which two items of earlier literature are cited together by the later literature." It allows to monitor the development of scientific fields (Garfield et al., 1983; Small, 1973, p. 265) and it helps to understand the authors' influence on the formation of the research field (Culnan, 1986). We use the co-citation network of authors to understand the main theoretical currents of intuition, as well as the formation of dialogues or 'invisible faculties.'

We carry out the analysis of social networks with the support of VOSviewer 1.6.13 and Pajek64 5.08 software. VOSviewer allows the understanding of bibliometric networks through map visualization, being an easy way to interpret a large volume of data (Van Eck \& Waltman, 2010). We use the document citation network (VOSviewer) and the main path analysis (Pajek), which indicates the main advances in the subject. Pajek software enables the analysis and design of social networks (De Nooy et al., 2018). We analyzed the local key-routes through the reference documents to understand the research field's key-routes and evolution (De Nooy et al., 2018; Mrvar \& Batagelj, 2016). The results identify the main existing networks of influential researchers in a specific field of research. These social networking techniques used also suggest trends based on identifying gaps in the literature (De Nooy et al., 2018; Zhao \& Strotmann, 2015).

Together with the social network, we carry out a systematic literature review that involves rigorous criteria applied in three stages: planning, execution, and reporting. "A comprehensive and unbiased search is one of the fundamental differences between a traditional narrative review and a systematic review" (Tranfield et al., 2003, p. 215). During the first stage, we defined the objective of the research and identified the database. We chose the Web of Science's Social Sciences Citation Index (SSCI) database for their recognition in social sciences research, allowing a considerable screening set of articles and offering analysis reports.

In the second stage, we defined the criteria for searching the articles; our search was restricted to the topic (title, keywords, or abstract) using the keywords 'intuition' and its derivatives (TS=intuit*). As a selection criterion, we used: language 'English,' document type 'article,' or 'review'; the Web of Science Category (WC) equal 'business' OR 'management.' The WC field presents journals classified in shared areas, with this, we did a second filter excluding the other areas, leaving only 'business' OR 'management' OR 'psychology' OR 'education' OR 'public administration.' These criteria result in 887 papers published in journals, 1968 to 2019 (search conducted on January 22, 2020). After we performed some tests, we found that, specifically for the main path analysis, it would be essential to select articles with a greater focus on the theme. We applied another filter, selecting only those papers that contained the words intuition or cognition and their derivatives ('intuit*', or 'cognit*') in the title, reducing the database to 151 articles, however with the potential to offer a more significant explanation of intellectual history.

Finally, we also perform content analysis as a way to complement the social network analysis and systematic review. This technique allows to explore information systematically using qualitative databases through the inductive method in which "categories are derived from data during data analysis" (Hsieh \& Shannon, 2005, p. 1285) and it offers significant advantages for management research (Duriau et al., 2007), for example, a rich understanding of the phenomenon (Hsieh \& Shannon, 2005). Content analysis presupposes three stages: (i) pre-analysis (organization of the material), (ii) exploration of the 
material (definition of the analysis categories), and (iii) treatment of the results through critical and reflective analysis (Bardin, 2011). Pre-analysis: based on the criteria previously defined to achieve the research objective, we arrived at a database. From this, we first defined the analysis plan (Bardin, 2011). Exploration of the material: posteriorly, we collected the information from the articles and developed the database. Finally, treatment of the results through critical and reflective analysis: we analyzed the information, summarized, coded, and categorized, identifying the main contributions of the studies, as well as the research gaps. "Categories are patterns or themes that are directly expressed in the text or are derived from them through analysis" (Hsieh \& Shannon, 2005, p. 1285).

\section{RESULTS PRESENTATION}

The research on intuition is relatively recent, with $85 \%$ of the articles published in the last 20 years, with the publication going from 129 (1968-1999) to 758 (2000-2019). We followed the recommendation to divide our analysis into five periods according to the volume of publication, as well as other studies in other areas using the social network technique (see Rossetto et al., 2018). It allows a greater longitudinal understanding of the evolution of research. Therefore, the first period consists of 32 years of research (1968-1999), marked by a small number (14,5\%) of publication. The subsequent periods in five years each. Due to the growing interest of researchers on the subject (Table 1).

Table 1. Database: Academic production by period

\begin{tabular}{lcccccc}
\hline Indicators & $\begin{array}{c}\text { 1st Period } \\
\mathbf{1 9 6 8 - 1 9 9 9}\end{array}$ & $\begin{array}{c}\text { 2nd Period } \\
\mathbf{2 0 0 0 - 2 0 0 4}\end{array}$ & $\begin{array}{c}\text { 3rd Period } \\
\mathbf{2 0 0 5 - 2 0 0 9}\end{array}$ & $\begin{array}{c}\text { 4th Period } \\
\mathbf{2 0 1 0 - 2 0 1 4}\end{array}$ & $\begin{array}{c}\text { 5th Period } \\
\mathbf{2 0 1 5 - 2 0 1 9}\end{array}$ & $\begin{array}{c}\text { Overall period } \\
\mathbf{1 9 6 8 - 2 0 1 9}\end{array}$ \\
\hline \# of papers & 129 & 86 & 149 & 239 & 284 & $\mathbf{8 8 7}$ \\
\hline \# of journals & 75 & 60 & 127 & 216 & 275 \\
\hline h-index & 50 & 39 & 49 & 44 & $\mathbf{7 5 3}$ \\
\hline
\end{tabular}

Source: Research data (Web of Science's - SSCI database).

We note that 523 papers (59\%) were published in the last ten years (2010-2019), it shows a significant increase in authors' interest. Some explanations may help to understand this increase. Firstly, studies offered important definitions and theoretical explanations (e.g., Dane \& Pratt, 2007; Sinclair \& Ashkanasy, 2005). Another explanation may be that prestigious academic conferences such as the Academy of Management Proceedings started in 2009 an exclusive symposium to discuss intuition that happens to this day.

In total, these articles cited 40.358 references, on average 45 per study. They resulted in a knowledge base of 38.122 articles used as a source for the production of knowledge in the intuition area in the last 52 years. The h-index is equal to 97; that is, it has at least 97 articles with at least 97 citations. This index evaluates the number of articles about the impact of the number of citations received (Hirsch, 2005).

\section{Authors' co-citation networks}

We performed some social network analysis to understand the evolution of the knowledge of intuition in decision-making over time. Co-citation by authors to identify the main theoretical dialogues and 'invisible faculties.' Posteriorly, the main path analysis to understand the main advances, as well as emerging subjects.

In general, the analysis of social networks through co-citations (cited references) of the 887 articles on intuition shows that the research on intuition caught the attention of 23,460 researchers from different areas. Applying the filter of at least 45 citations, we identified the 35 most influential authors who form four 'invisible faculties,' as shown in Figure 2. 
Figure 2. Authors' co-citation networks - 'Invisible Faculties' (1968-2019)

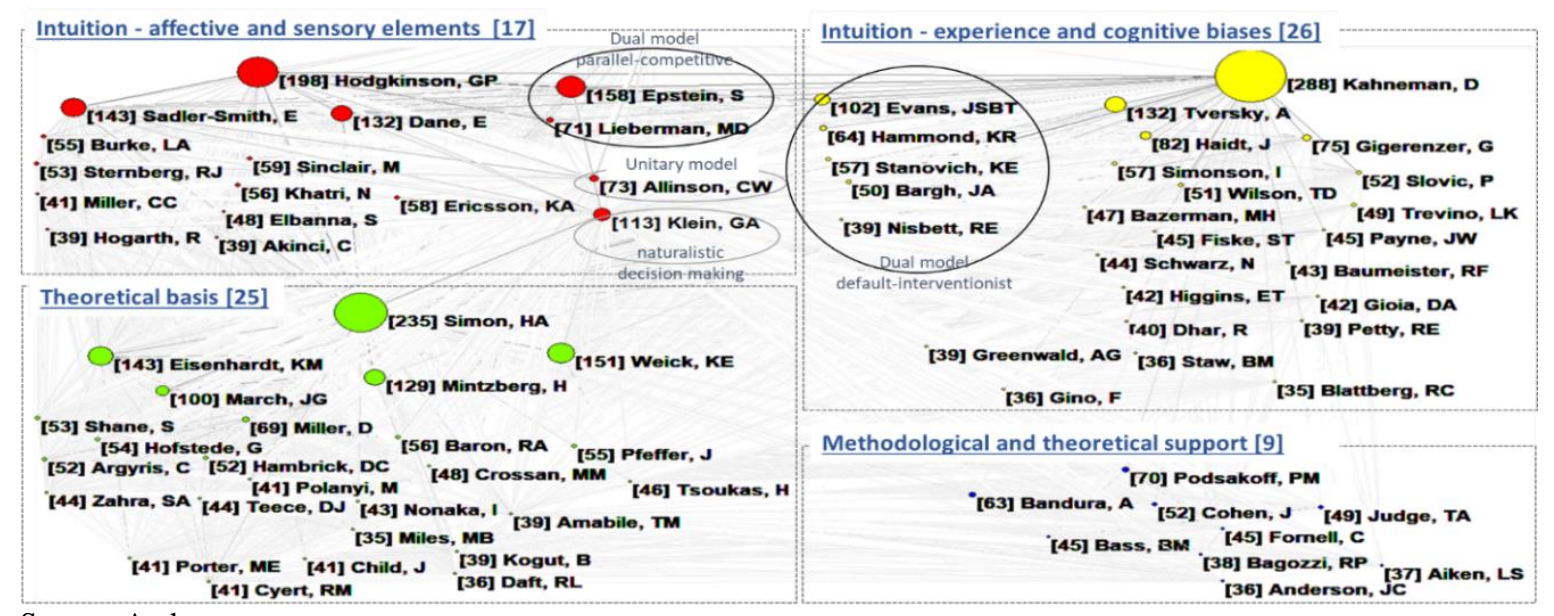

Source: Authors.

Web of Science: 887 articles (1968-2019). Analysis performed in the VOSviewer software.

Criteria: 77 most co-cited authors with at least 35 citations. Pajek software was used to improve visualization.

Intuition research is divided into two main theoretical currents (Van Riel \& Horváth, 2014), illustrated in Figure 2. In the first approach (yellow cluster), researchers have been influenced by economic theories. They understand intuition as behavioral aspects based on experience and cognitive biases. The answers happen through the recognition of rules in the heuristic system based on the tacit knowledge accumulated over time (e.g., Gigerenzer et al., 1999; Kahneman et al., 2019; Tversky \& Kahneman, 1974). Kahneman and Tversky were famous for "behavioral finance" because they noticed investment decision-making processes that are not related to maximizing the operation, but due to cognitive biases.

In general, these authors believe that the answers first happen through intuition and may (or not) be changed later by the intervention of the analytical system. In this perspective, analytical decisionmaking is a way of rationalizing intuitive decisions (Haidt, 2001). The theory of dual processing explains this process through default-interventionist. That is, processing occurs sequentially. Intuition is the first to arrive (System 1) can be accepted. That is, processing occurs sequentially. Intuition is the first to arrive (System 1) and may be taken, or there may be intervention by the analytical system (System 2), depending on the processing capacity (Evans, 2007; Evans \& Stanovich, 2013; Hodgkinson \& SadlerSmith, 2018; Stanovich \& West, 2000).

Theories in the fields of psychology and management influenced the authors of the second theoretical current (red cluster). They understand the relevance of the experience. However, they focus on the affective and sensory elements of the intuitive process (e.g., Akinci \& Sadler-Smith, 2012; Dane \& Pratt, 2007; Hodgkinson et al., 2008; Hodgkinson \& Sadler-Smith, 2018; Sadler-Smith et al., 2008; Sinclair, 2010; Sinclair \& Ashkanasy, 2005). Unlike the yellow cluster, they understand processing can occur simultaneously, and conflicts between systems can emerge, explained by the parallel-competitive approach (Epstein, 1990; Epstein et al., 1996) in the competition for control (Hodgkinson \& SadlerSmith, 2018).

The third cluster (green) is composed of classic authors. They present theoretical bases from other areas of knowledge in a complementary way to the two theoretical currents of intuition (clusters yellow and red). Management: the authors offer arguments to explain decision-making in management. Some previously presented, Bounded Rationality Theory (Simon, 1955, 1956), Garbage Can Model (Cohen et al., 1972; March \& Simon, 1958), and Sensemaking (Weick, 1995). Additionally, Mintzberg explains the strategic decisions in organizations to demystify the idea of the manager as having systematic control of activities, recognizing the importance of analysis and intuition in decision-making, proposing the use of analysis and logic more frequently in the planning and creativity and intuition in management (e.g., Mintzberg et al., 1976; Mintzberg \& Waters, 1985). Strategy: for example, Eisenhardt was a pioneer in urging organizations to adopt more holistic approaches to unscheduled decisions. It studies the use of simple heuristic rules and interaction with strategic decision-making. (Eisenhardt \& Bourgeois III, 1988). Miller explains the relationship between strategy making and the environment (Miller \& Friesen, 1983). 
Entrepreneurship: for example, "The promise of entrepreneurship as a field of research" is one of the most influential papers, whose authors offer important theoretical definitions of entrepreneurship, stimulating debate for the evolution of the field (Shane \& Venkataraman, 2000). Zahra and George (2002) connect dynamic capabilities with entrepreneurship, differentiate between new ventures, and establish established companies. They propose a relationship between dynamic capabilities and substantive resources, being moderated by organizational knowledge and skills. Baron (1998) explains cognitive (such as the role of affection) and social factors. Innovation: for example, the theory of "Dynamic Capabilities" (skills, organizational and structures processes, decision rules, among others) helps in strategic management by detecting opportunities and threats that are transformed into learning and innovation, generating competitive advantage (Teece et al., 1997). The theory of "Organizational Knowledge Creation" explains that the ability of a company to create new knowledge, disseminate it throughout the organization, and incorporate it into products, services, and systems is the key to continuous innovation and business success (Nonaka \& Takeuchi, 1995).

Finally, the blue cluster represents methodological and theoretical support for the three groups. The authors proposed measurement techniques, conceptual models, or complementary theories. The vast majority of studies offer a methodological basis (Aiken, Anderson, Bagozzi, Cohen, Fornell, and Podsakoff) and the rest theoretically supports, social cognitive theory, self-efficacy (Bandura, Albert), leadership style (Bass, Bernard), and organizational behavior (Judge, Timothy).

The authors' co-citation map helps to visualize and understand the 'invisible faculties', that is, the different theoretical currents. We can easily see the existing academic dialogues, the influential authors in each current, who they follow, their followers (theoretical basis), and the differences between theoretical currents. Thus, it contributes to a greater understanding of the phenomena studied in an expanded way.

The identification of 'invisible faculties' contributes to clarifying the authors' theoretical position about the default-interventionist and parallel-competitive approaches, which, until now, it has seemed implicit in the literature. It is "the time has come for researchers in management and organization studies (MOS) to position their work more clearly and explicitly in alignment with one or other of the default-interventionist and parallel-competitive camps" (Hodgkinson \& Sadler-Smith, 2018, p. 29). Subsequently, we applied the main path analysis to complement our contributions as a 'magnifying glass' to understand the main milestones in the intellectual history of intuition in decision-making.

\section{Main Path analysis}

The citations of the researchers' articles form a network of influential paths containing intellectual advances in the scientific field. Path analysis identifies the main flow for the literature review. Thus, this technique allows the understanding of the evolution of the research field through the search for patterns that reflect the history and indicate the interconnectivity between the authors (De Nooy et al., 2018).

We identified 15 milestones through main path analysis using the technique of local key-routes. They summarize intellectual developments in the longitudinal study of intuition during 52 years of research, as shown in Figure 3. The arrowhead indicates the reading direction for understanding this story. It is important to emphasize that this technique identifies the flow through the cited references. Therefore, the most cited articles do not necessarily define the results (Liu \& Lu, 2012).

\section{Figure 3. Main Path analysis}

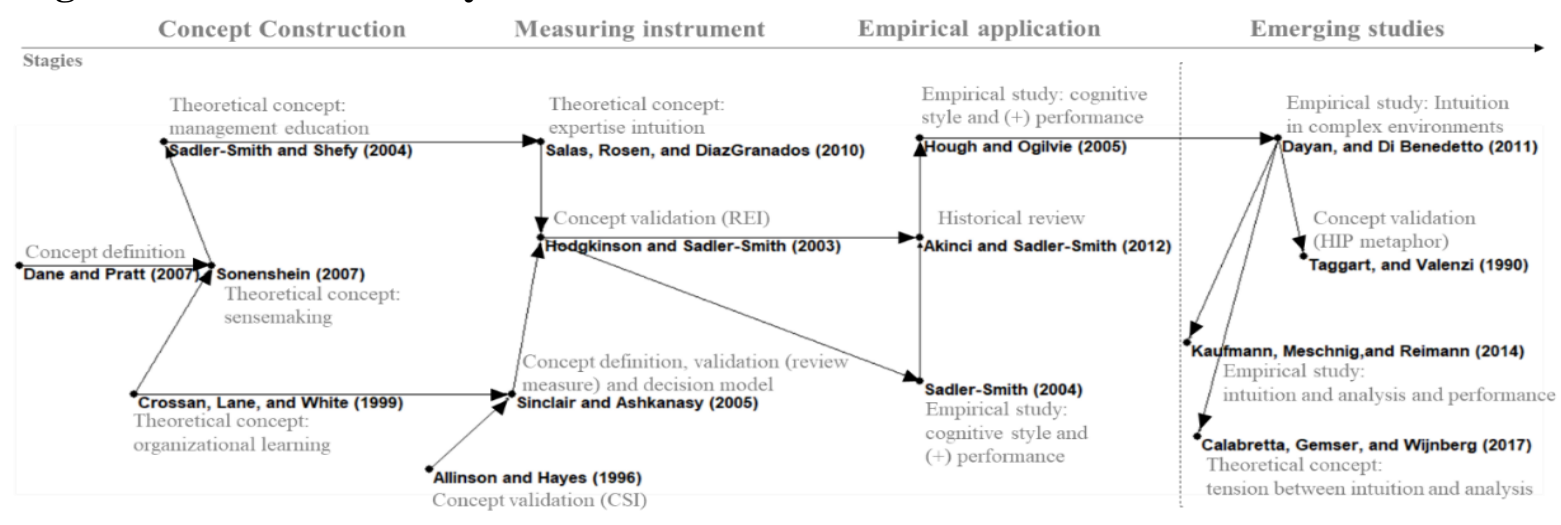


Source: Authors. Citation documents analysis in the VOSviewer software of the $151^{1}$ papers with a minimum of 15 citations, resulted in a network of 84 articles. From the results, we performed the main path analysis in the Pajek software using the local key-routes ${ }^{2}$ method, which indicated 15 fundamental readings. 'Web of Science database with 'intuit*' or 'cognit*' in the title in the area of Business and Management. ${ }^{2}$ We did different tests and analyses and found that the local key-route explained better according to the systematic literature review.

From the content analysis, we classified the 15 articles into five categories: concept definition (Dane \& Pratt, 2007; Sinclair \& Ashkanasy, 2005), theoretical concept (Calabretta et al., 2017; Crossan et al., 1999; Sadler-Smith \& Shefy, 2004; Salas et al., 2010; Sonenshein, 2007), concept validation (Allinson \& Hayes, 1996; Hodgkinson \& Sadler-Smith, 2003; Sinclair \& Ashkanasy, 2005; Taggart \& Valenzi, 1990), empirical study (Dayan \& Di Benedetto, 2011; Hough \& Ogilvie, 2005; Kaufmann et al., 2014; Sadler-Smith, 2004), and historical review (Akinci \& Sadler-Smith, 2012).

Theoretical concept - Sensemaking Model: Theoretical concept - Sensemaking Model: The main path analysis begins with the study of Dane and Pratt (2007) with the conceptual definition of intuition. Posteriorly, Sonenshein (2007) presents the Sensemaking-Intuition Model (SIM) as an alternative to rationalist approaches. The model explains that intuition happens in three stages: issue construction (from the social stimulus in uncertain environments that are affected by expectations), instantly makes an intuitive judgment (comes from experience and social pressures), and subsequently occurs an explanation and justification for the individual himself and other people.

Theoretical concept - Organization Learning: Next, the technique indicates the reading of the study of Crossan et al. (1999) presents intuition as one of the ways organizations learning in the 4I framework: intuiting, interpreting, integrating, and institutionalizing. This study was previously published in 1999. This technique first indicates the reading of Dane and Pratt (2007) due to the need to know the definition of intuition to understand other studies. This reading direction presented is one of the advantages and a differential of this methodology and helps in understanding the research field in a more profound way.

Concept Definition - Decision Model: Posteriorly, Sinclair and Ashkanasy (2005) present a new concept of intuition. However, we can see that this analysis indicates the study of Dane and Pratt (2007) as most used in the literature, because, even if it was published later, it starts the flow in support of other articles. However, some authors indicate the need for further studies that seek to understand the theoretical concepts of intuition (Akinci \& Sadler-Smith, 2012; Burke \& Sadler-Smith, 2006; Dane \& Pratt, 2007; Hodgkinson et al., 2009). Sinclair and Ashkanasy (2005) also present a model integrating analytical and intuitive decision-making that is affected by aspects such as problem characteristics, decision characteristics, personal disposition, and decision-making context. Additionally, the authors suggest that the effect is moderated by affect and gender.

Concept validation - Measuring Instrument: Taggart and Valenzi (1990), Allinson and Hayes (1996), Sinclair and Ashkanasy (2005), and Hodgkinson and Sadler-Smith (2003) present scales for measurement. At the same time, these studies indicate a discussion on how to process information, if in a dual way (two systems) (Hodgkinson \& Sadler-Smith, 2003; Sinclair \& Ashkanasy, 2005; Taggart \& Valenzi, 1990) or if continuous unitary (Allinson \& Hayes, 1996). There is an open debate about how information processing occurs, whether dual or unitary (Hodgkinson \& Sadler-Smith, 2018). There are also study opportunities to understand the measurement instrument (Akinci \& Sadler-Smith, 2012).

Theoretical Concept - Management Education: Some researchers asked: Is it possible to develop intuition? (Agor, 1986; Khatri \& Ng, 2000). Sadler-Smith and Shefy (2004) argue that it is possible and offer some guidelines for teaching intuition and also alerting some points of limitations. Different authors have indicated different research opportunities in management education (Burke \& SadlerSmith, 2006; Dörfler \& Ackermann, 2012; Okoli \& Watt, 2018; Sadler-Smith \& Shefy, 2007; Sinclair et al., 2010).

Theoretical Concept - Types of intuition: Salas et al. (2010) define expertise intuition as related to the individual's knowledge and experience, linked to decision-making under pressure, in which it usually appears quickly, also supported by other authors (Dane \& Pratt, 2007; Sinclair, 2010). Sinclair (2010) complements and indicates what expertise has to do with the past and indicating two other types related to the present (intuitive creation and problem-solving) and the future (intuitive foresight). Intuitive creation and problem-solving (or creative intuition or entrepreneurial intuition) although it may originate from the past (learning, living, experience), it has a present critical element, it is linked to innovation or invention (Crossan et al., 1999; Dane \& Pratt, 2009; Sadler-Smith, 2015; Sinclair, 2010; 
Sinclair \& Ashkanasy, 2005). Intuitive foresight, the scope is broader, uses knowledge, future-oriented experiences (Sinclair, 2010). For a complete review of the types of intuition: aesthetic intuition, affective intuition, creative intuition, expert intuition, holistic intuition, inferential intuition, intellectual intuition, intuitive judgment, intuitive insight, moral intuition, religious intuition and social intuition (see SadlerSmith, 2019, p. 10).

Historical Review: Akinci and Sadler-Smith (2012) carry out a historical review on intuition since the first study in 1938. In general, this study consolidates the previous concepts presented; however, broadly, being therefore complementary to the reading and not substitutable to the previous ones. Until then, the studies indicated the definition, as it happens, the validation through the measurement of instruments and scales, also indicated that there are different types of intuition, which is also possible to develop in the organizational environment. However, can intuition be related to performance? (Allinson et al., 2001; Armstrong \& Hird, 2009; Sadler-Smith \& Shefy, 2007).

Empirical Studies - Performance: Different authors find positive relationships between intuition and performance in different companies (Hough \& Ogilvie, 2005; Kaufmann et al., 2014; Sadler-Smith, 2004; Taggart \& Valenzi, 1990). Other studies have indicated that the simultaneity between intuition and analysis can optimize decision-making (Dane \& Pratt, 2009; Eling et al., 2015; Groves et al., 2011; Intezari \& Pauleen, 2017; Kaufmann et al., 2014). There are still different research opportunities (see Baldacchino et al., 2015; Groves et al., 2011).

Empirical Studies - Complex environments: Posteriorly, Dayan and Di Benedetto (2011) indicated there is greater use of intuition in environments of uncertainty, other authors supported this view (Elbanna \& Fadol, 2016; Khatri \& Ng, 2000; Robinson et al., 2017; Van Riel \& Horváth, 2014). In these cases, intuition can happen accompanied by analysis (Bakken et al., 2017; Dayan \& Di Benedetto, 2011).

Theoretical Concept - Intuition and Analysis: Calabretta et al. (2017) recognize the need for simultaneous use of intuition and analysis in strategic decisions. However, there may be tension between the processes because they have very different characteristics (Bakken et al., 2017; Keller \& SadlerSmith, 2019; Okoli \& Watt, 2018; Sayegh et al., 2004; Sinclair et al., 2010). Calabretta et al. (2017) suggest a conceptual model assist in managing some situations. These authors indicate different research opportunities on this topic.

In general, as we can see in Figure 3, the main path analysis directs reading by the sequence of theoretical knowledge for the evolution of intuition in decision-making in four stages, regardless of the chronological order. This is a differential compared to other methodologies and previous studies, and it is also an advantage of this technique. It provides an in-depth understanding of the theme and indicates the essential concepts to be understood in a targeted and structured way. A significant definition for the theme can be published in different chronological time. What happens in intuition research and can happen in other subjects, areas, or fields of study.

At first, the technique indicates studies for the understanding of the main concepts, directing some papers that were published later. However, the advance reading is essential for theoretical understanding. Subsequently, we observed a stage of validation of the concepts of intuition, through the construction of scales and indication of existing measurement instruments. Then, the empirical application takes place, including understanding the relationship between intuition and performance. Finally, the analysis indicates the emerging studies for understanding the simultaneity of intuition and analysis in decision-making in different contexts. For example, in environments of uncertainty and complexity, and crisis management - indicating that as there are differences between the characteristics of the intuitive and analytical systems, this can generate tension between the processing modes.

\section{RESEARCH LIMITATIONS AND AGENDA FOR FUTURE STUDIES}

One of the main limitations of this study is the criteria for searching articles, such as the choice of database, and filters applied. Additionally, recently published articles did not have enough time to be cited and appear in the citations and co-citations network analysis. There may also be possible failures to record information in the database used for information extraction, such as misspellings, inconsistency (words written in different ways - hyphen), and possible homonym (different authors with the same name) to registration problems. Additionally, databases contain only the data from the first author of the 
referenced articles, so there may be problems in multi-authoring cases. Moreover, it is a challenging study that requires a deep understanding and analysis of the different fields of research.

The mixed methods applied in this research (main path analysis, systematic literature review, content analysis) indicate some emerging areas and gaps in the literature (Table 2).

\section{Table 2. Theoretical advances: Gaps in the literature by categories}

\section{Gaps in the literature by categories}

Theoretical Concept: There are different definitions for intuition (e.g., Dane \& Pratt, 2007; Sadler-Smith, 2016b; Sinclair \& Ashkanasy, 2005). It requires further studies in search of a global definition (Akinci \& Sadler-Smith, 2012). There are different research opportunities. To differentiate and to understand the role of intuition from other constructs (e.g., instinct, insight, creativity, tacit knowledge, implicit learning, wisdom, and deep intelligence) (Burke \& Sadler-Smith, 2006; Dane \& Pratt, 2007; Hodgkinson et al., 2009). To understand the concept of intuition and its relation to other modes of decision-making, such as rationality (Elbanna \& Fadol, 2016). To develop a conceptual framework of personality theories to explain intuitive insights beyond the scope of nonconscious pattern recognition (Sinclair \& Ashkanasy, 2005). To understand under what circumstances and under what work tasks, whether default-interventionist and parallel-competitive approaches can happen alternatively. To re-theorize the approaches to the intuition that have been developed largely isolated from the conventional theory of double processes (e.g., recognition-primed decision (RPD) theory of intuitive expertise) (Hodgkinson \& Sadler-Smith, 2018).

Method: Measuring instrument: there is still an open debate to understand how information processing occurs - dual or unitary (Hodgkinson \& Sadler-Smith, 2018). To understand other components of intuitive and analytical processing (e.g., creative intuitions, moral, social judgments) as complements to the Rational-Experiential Inventory scale (Akinci \& Sadler-Smith, 2012).

Research methods: combining retrospective interviews with other research methods (Calabretta et al., 2017). The application of ethnographic techniques and related approaches, such as verbal protocol analysis, can help to understand the interaction of intuition and analysis in situations of tension in uncertain environments (Hodgkinson \& Sadler-Smith, 2018).

Intuition model: Developing models of antecedent and outcomes of intuition in entrepreneurship (Baldacchino et al., 2015), a framework with individual factors (e.g., personal skills, experience, emotions, confidence, characteristics of decision-makers), contextual factors, organization factors, trust, and team empowerment), outcomes (organizational performance, decision quality, improvisation) and preference for a thinking style as a moderator (Elbanna, 2015; Elbanna \& Fadol, 2016; Matzler et al., 2014; Mikušková, 2017)

Management education: Developing managers, educators, and methods to evolve knowledge (Burke \& Sadler-Smith, 2006), to understand the potential challenges and barriers to facilitate effective intuitions and how to improve intuitive abilities (Dane \& Pratt, 2007; Mitchell et al., 2005; Sadler-Smith \& Shefy, 2007). To understand the characteristics of individuals who tend to rely more on simple schemes and heuristics, as they have difficulties in developing complex schemes or connections (Dane \& Pratt, 2007). To identify the specific situations in which intuition works best (Burke \& Miller, 1999). To provide a comprehensive tool for the educators of current and future knowledge workers for explaining intuition (Dörfler \& Ackermann, 2012). To develop training or learning (Okoli \& Watt, 2018; Sinclair et al., 2010). To teach managers to discuss their intuitive feelings and check the accuracy and efficiency of their intuition-based decisions (Mikušková, 2017). To understand whether complex and relevant expert domain schemes can be transferred to automated information systems or others (Dane \& Pratt, 2007).

Entrepreneurial intuition: To understand cognitive style and the role of intuition and analysis in the business process and tasks (Baldacchino et al., 2015; Blume \& Covin, 2011; Chaston \& Sadler-Smith, 2012; Grégoire et al., 2015; Groves et al., 2011; SadlerSmith, 2004, 2016a). To investigate how other approaches (effectuation, bricolage) and intuition are linked (Blume \& Covin, 2011; Grégoire et al., 2015; Mitchell et al., 2005). To understand the harmony between intuitive entrepreneurs with the somatic state's awareness and the relationship with business success and failure (Sadler-Smith, 2016a). To analyze the causal relationships that link the perceptions of self-efficacy and intentionality with cognitive style (Kickul et al., 2009).

Intuition and analysis: Simultaneity or coexistence: investigating the combination of decision-making approaches is most beneficial for different types of decision-making problems (Eling et al., 2015). To understand how intuition and analysis interact when experienced decision-makers are confronted with scenarios in their domain of expertise, but their specialized judgment is confused by the uncertainty of the environment (Hodgkinson \& Sadler-Smith, 2018).

Tensions: investigating under what conditions external adjustment (e.g., cognitive style with the environment) is more or less important than internal adjustment (for example, cognitive style with structure) as a predictor of company success. To understand when these two types of adjustments are equally important; and when these two types of adjustments are incompatible. To investigate the effective alignments between cognitive style and other dimensions of decision-making style (e.g., participation, and risk) (Covin et al., 2001). To understand of cognitive styles and intercultural conflict (Allinson \& Hayes, 2000). To apply the "managing the intuition - rationality tension" framework in other contexts and at the group level and to understand news factors; and investigate whether it explains cases of multiple paradoxes (Calabretta et al., 2017). To apply and understand the framework for the integration of theories of paradox and double processes in different contexts (Keller \& Sadler-Smith, 2019)

Practice: integrating intuition and rationality in their working practices (Calabretta et al., 2017). To understand how managers can know when they rely too much or too little on their intuition as the fundamental basis for strategic decision-making (Covin et al. 2001).

Source: Authors.

We indicate research opportunities for the evolution of intuition in decision-making on different topics. To understand and deepen theoretical concepts theoretical concept, application of mixed methods and improvement of scales, development of models that explain the antecedents and outcomes of intuition, development of tools and application in management education, understanding intuition about 
different topics of entrepreneurship, and understanding the relationship of simultaneity, coexistence, and tensions between intuition and analysis.

\section{THEORETICAL AND PRACTICAL CONTRIBUTIONS}

This study offers theoretical contributions as it offers a greater understanding of intuition in decision-making. This is the first study to use mixed methods (social networks together with systematic literature review and content analysis) to identify 'invisible faculties' on this subject. Second, from this, we identify a map that helps in understanding, visualizing, and differentiating the main existing networks of influential researchers in each theoretical dialogue, authors who follow the same approaches, and the theoretical positioning of the authors through the academic and methodological basis; the last one so far implicit in the literature (Hodgkinson \& Sadler-Smith, 2018). Third, this study is the first to apply the main path analysis to this theme. It contributes to an initial review of the milestones through the flow of knowledge and the evolution of the research by reading 15 articles in a way guided by thematic understanding and not necessarily in chronological order, as presented in previous studies. This is one of the advantages and a differential of this technique, as it helps in understanding the theme studied more deeply. Fourth, it contributes to the theoretical evolution of the subject, indicating emerging studies and a research agenda based on the identification of gaps in the literature. Finally, the methods used in this article can be applied in other areas, themes, or research fields to carry out comprehensive reviews (with a high volume of publication) and identify flows, optimizing the choice of the first articles and direct reading by theoretical knowledge and not necessarily chronological.

This study also contributes to the practice. First, the presentation of the theoretical evolution of intuition in decision-making in a review and structured way can assist in the understanding of entrepreneurs, managers, researchers, professionals, students, educational institutions managers, among others. From there, they can reflect on their practices and analyze how they have used their intuition. Second, it can help and encourage the application and the development of tools for teaching, training, or discussing the topic. Third, the main path analysis is very useful for people who are not knowledgeable about the subject, indicating the main documents and the reading order to familiarize themselves with the main milestones and emerging areas. Therefore, this research can contribute as a way of indicating the appropriation of knowledge through an initial review and directed to professionals, managers, entrepreneurs, teachers, students, researchers, educational institutions, and managers.

\section{FINAL CONSIDERATIONS}

The authors' co-citation analysis shows a broad view of the research area, and the main path analysis helps in understanding the main milestones. The analyzes applied in the mixed method and, in a complementary way, provide a holistic view of the intellectual history of intuition in decision-making. The co-citation analysis explains that the theoretical debates are divided into two main streams. A group of researchers understands intuition as behavioral aspects based on experience and cognitive biases and follow the default-interventionist approach. The second current follows the parallel-competitive approach. The authors understand intuition as the result of experience and, at the same time, the importance of the affective and sensory elements.

Both groups have theoretically based their studies on concepts from other areas (e.g., management, entrepreneurship, innovation, strategy), mainly in the explanation of non-linear decisionmaking. It is also possible to identify methodological bases and complementary theories. This analysis makes it possible to identify 'invisible faculties' that help in understanding the authors' theoretical position that it was implicit in the literature.

The main path analysis indicates 15 articles that explain the milestones in the intellectual history of intuition in decision-making over 52 years. We categorize into four respective main stages: concept construction, validation through measurement instruments, empirical application, and emerging studies. The publications that explain the fundamental concepts can be published in a different chronological order. However, this analysis directs the reading in a structured way in order of theoretical knowledge, which contributes to the deepening of the subject and differs from other methodologies and previous studies.

Finally, this study's mixed-method (systematic review, content analysis, and social network) can be replicated and encourage other themes, areas, or research fields. This allows for a structured review to understand the intellectual history of the studied phenomena - regarding the influencing authors, their 
theoretical positioning, the theoretical dialogues, and 'invisible faculties,' and the fundamental theoretical and methodological bases used.

\section{REFERENCES}

Agor, W. H. (1986, Win). The logic of intuition: How top executives make important decisions. Organizational Dynamics, 14(3), 5-18.

Akinci, C., \& Sadler-Smith, E. (2012, Mar). Intuition in Management Research: A Historical Review. International Journal of Management Reviews, 14(1), 104-122.

Allinson, C. W., Armstrong, S. J., \& Hayes, J. (2001, Jun). The effects of cognitive style on leader-member exchange: A study of manager-subordinate dyads. Journal of Occupational and Organizational Psychology, 74, 201-220.

Allinson, C. W., Chell, E., \& Hayes, J. (2000). Intuition and entrepreneurial behaviour. European Journal of Work and Organizational Psychology, 9(1), 31-43.

Allinson, C. W., \& Hayes, J. (1996, Jan). The Cognitive Style Index: A Measure of Intuition-Analysis For Organizational Research. Journal of Management Studies, 33(1), 119-135.

Allinson, C. W., \& Hayes, J. (2000, Feb). Cross-national differences in cognitive style: implications for management. International Journal of Human Resource Management, 11(1), 161-170.

Armstrong, S. J., \& Hird, A. (2009, Dec). Cognitive Style and Entrepreneurial Drive of New and Mature Business Owner-Managers. Journal of Business and Psychology, 24(4), 419-430.

Bakken, B. T., Hærem, T., \& Meland, N. T. (2017). The Strategic Adaptive Decision (SAD) Model. Academy of Management Proceedings,

Baldacchino, L., Ucbasaran, D., Cabantous, L., \& Lockett, A. (2015, Apr). Entrepreneurship research on intuition: A critical analysis and research agenda. International Journal of Management Reviews, 17(2), 212-231.

Bardin, L. (2011). Análise de conteúdo (L. A. Reto \& A. Pinheiro, Trans.; Vol. 70). Edições 70.

Baron, R. A. (1998, 1998/07/01/). Cognitive mechanisms in entrepreneurship: Why and when enterpreneurs think differently than other people. Journal of Business Venturing, 13(4), 275-294.

Behn, R. D. (1988). Management by groping along. Journal of policy analysis and management, 7(4), 643-663.

Blume, B. D., \& Covin, J. G. (2011, Jan). Attributions to intuition in the venture founding process: Do entrepreneurs actually use intuition or just say that they do? Journal of Business Venturing, 26(1), 137-151.

Burke, L. A., \& Miller, M. K. (1999, November, 1999). Taking the mystery out of intuitive decision making. Academy of Management Perspectives, 13(4), 91-99.

Burke, L. A., \& Sadler-Smith, E. (2006, Jun). Instructor intuition in the educational setting. Academy of Management Learning \& Education, 5(2), 169-181.

Burt, R. S. (1977). Positions in Multiple Network Systems, Part One: A General Conception of Stratification and Prestige in a System of Actors Cast as a Social Topology. Social Forces, 56(1), 106-131.

Calabretta, G., Gemser, G., \& Wijnberg, N. M. (2017, Apr). The Interplay between Intuition and Rationality in Strategic Decision Making: A Paradox Perspective. Organization Studies, 38(3-4), 365-401.

Carter, C. R., Kaufmann, L., \& Wagner, C. M. (2017, Jun). Reconceptualizing Intuition in Supply Chain Management. Journal of Business Logistics, 38(2), 80-95.

Chaston, I., \& Sadler-Smith, E. (2012, September). Entrepreneurial cognition, entrepreneurial orientation and firm capability in the creative industries. British Journal of Management, 23(3), 415-432.

Claxton, G., Owen, D., \& Sadler-Smith, E. (2015, Feb). Hubris in leadership: A peril of unbridled intuition? Leadership, 11(1), 57-78.

Cohen, M. D., March, J. G., \& Olsen, J. P. (1972). A garbage can model of organizational choice. Administrative Science Quarterly, 17(1), 1-25.

Covin, J. G., Slevin, D. P., \& Heeley, M. B. (2001, Apr). Strategic decision making in an intuitive vs. technocratic mode: structural and environmental considerations. Journal of Business Research, 52(1), 51-67.

Crossan, M. M., Lane, H. W., \& White, R. E. (1999, Jul). An organizational learning framework: From intuition to institution. Academy of management review, 24(3), 522-537.

Culnan, M. J. (1986). The Intellectual Development of Management Information Systems, 1972-1982: A CoCitation Analysis. Management Science, 32(2), 156-172.

Dane, E., \& Pratt, M. G. (2007, Jan). Exploring intuition and its role in managerial decision making. Academy of management review, 32(1), 33-54.

Dane, E., \& Pratt, M. G. (2009). Conceptualizing and measuring intuition: A review of recent trends. In G. P. Hodgkinson \& J. K. Ford (Eds.), International review of industrial and organizational psychology (Vol. 24, pp. 1-40). John Willey \& Sons Ltd.

Davis, J. H. (1992, Jun). Some compelling intuitions about group consensus decisions, theoretical and empiricalresearch, and interpersonal aggregation phenomena - selected examples, 1950-1990. Organizational Behavior and Human Decision Processes, 52(1), 3-38. 
Dayan, M., \& Di Benedetto, C. A. (2011, Mar). Team intuition as a continuum construct and new product creativity: The role of environmental turbulence, team experience, and stress. Research Policy, 40(2), 276-286.

De Nooy, W., Mrvar, A., \& Batagelj, V. (2018). Exploratory social network analysis with Pajek: Revised and expanded edition for updated software (Vol. 46). Cambridge University Press.

Dörfler, V., \& Ackermann, F. (2012, November). Understanding intuition: The case for two forms of intuition. Management Learning, 43(5), 545-564.

Duriau, V. J., Reger, R. K., \& Pfarrer, M. D. (2007, January). A Content Analysis of the Content Analysis Literature in Organization Studies: Research Themes, Data Sources, and Methodological Refinements. Organizational Research Methods, 10(1), 5-34.

Dutta, D. K., \& Thornhill, S. (2008). The evolution of growth intentions: Toward a cognition-based model. Journal of Business Venturing, 23(3), 307-332.

Eisenhardt, K. M., \& Bourgeois III, L. J. (1988). Politics of strategic decision making in high-velocity environments: Toward a midrange theory. Academy of Management Journal, 31(4), 737-770.

Elbanna, S. (2006, Mar). Strategic decision-making: Process perspectives. International Journal of Management Reviews, 8(1), 1-20.

Elbanna, S. (2015, Aug). Intuition in project management and missing links: Analyzing the predicating effects of environment and the mediating role of reflexivity. International Journal of Project Management, 33(6), 12361248 .

Elbanna, S., \& Fadol, Y. (2016, Sep). The role of context in intuitive decision-making. Journal of Management \& Organization, 22(5), 642-661.

Eling, K., Langerak, F., \& Griffin, A. (2015, Sep). The performance effects of combining rationality and intuition in making early new Product idea evaluation decisions. Creativity and Innovation Management, 24(3), 464-477.

Elsbach, K. D., \& Barr, P. S. (1999, March-April). The Effects of Mood on Individuals' Use of Structured Decision Protocols. Organization Science, 10(2), 181-198.

Epstein, S. (1990). Cognitive-experiential self-theory. In L. A. Pervin (Ed.), Handbook of personality: Theory and research (pp. 165-192). The Guilford Press.

Epstein, S., Pacini, R., Denes-Raj, V., \& Heier, H. (1996, August, 1996). Individual differences in intuitiveexperiential and analytical-rational thinking styles. Journal of personality and social psychology, 71(2), 390405.

Etzioni, A. (1992). Socio-economics: select policy implications. In S. E. G. Lea, P. Webley, \& B. M. Young (Eds.), New directions in economic psychology: Theory experiment and application (pp. 13-27). Edward Elgar.

Evans, J. S. B. T. (2007). On the resolution of conflict in dual process theories of reasoning. Thinking \& Reasoning, 13(4), 321-339.

Evans, J. S. B. T., \& Stanovich, K. E. (2013). Dual-Process Theories of Higher Cognition: Advancing the Debate. Perspectives on Psychological Science, 8(3), 223-241.

Garfield, E., Malin, M. V., \& Small, H. (1983). Citation data as science indicators. In Y. Elkana, J. Lederberg, R. K. Merton, A. Thackray, \& H. Zuckerman (Eds.), Toward a metric of science: The advent of sciences indicators (Vol. 6, pp. 580). John Wiley \& Sons.

Georgiou, I. (2014, March - April). Seeing the Forest for the Trees: An Atlas of the Politics-Administration Dichotomy. Public Administration Review, 74(2), 156-175.

Gigerenzer, G., Todd, P. M., \& ABC Research Group. (1999). Simple heuristics that make us smart. Oxford University Press.

Grégoire, D. A., Cornelissen, J., Dimov, D., \& van Burg, E. (2015, Apr). The mind in the middle: Taking stock of affect and cognition research in entrepreneurship. International Journal of Management Reviews, 17(2), 125142.

Groves, K., Vance, C., \& Choi, D. (2011, July). Examining entrepreneurial cognition: An occupational analysis of balanced linear and nonlinear thinking and entrepreneurship Success. Journal of Small Business Management, 49(3), 438-466.

Haidt, J. (2001). The emotional dog and its rational tail: A social intuitionist approach to moral judgment. Psychological Review, 108(4), 814-834.

Harvey, M., \& Novicevic, M. M. (2002, Sum). The hypercompetitive global marketplace: the importance of intuition and creativity in expatriate managers. Journal of World Business, 37(2), 127-138, Article Pii s10909516(02)00072-x.

Hirsch, J. E. (2005, November 15). An index to quantify an individual's scientific research output. Proceedings of the National Academy of Sciences of the United States of America, 102(46), 16569-16572.

Hodgkinson, G. P., Langan-Fox, J., \& Sadler-Smith, E. (2008, February). Intuition: A fundamental bridging construct in the behavioural sciences. British Journal of Psychology, 99(1), 1-27.

Hodgkinson, G. P., \& Sadler-Smith, E. (2003, Jun). Complex or unitary? A critique and empirical re-assessment of the Allinson-Hayes Cognitive Style Index. Journal of Occupational and Organizational Psychology, 76, 243268. 
Hodgkinson, G. P., \& Sadler-Smith, E. (2018). The dynamics of intuition and analysis in managerial and organizational decision making. Academy of Management Perspectives, 32(4), 473-492.

Hodgkinson, G. P., Sadler-Smith, E., Sinclair, M., \& Ashkanasy, N. M. (2009, May). More than meets the eye? Intuition and analysis revisited. Personality and individual differences, 47(4), 342-346.

Hough, J. R., \& Ogilvie, D. (2005, Mar). An empirical test of cognitive style and strategic decision outcomes. Journal of Management Studies, 42(2), 417-448.

Hsieh, H.-F., \& Shannon, S. E. (2005, November). Three approaches to qualitative content analysis. Qualitative Health Research, 15(9), 1277-1288.

Intezari, A., \& Pauleen, D. J. (2017). Conceptualizing Wise Management Decision-Making: A Grounded Theory Approach. Decision Sciences, 49(2), 335-400.

Janis, I. L., \& Mann, L. (1977). Decision making: A psychological analysis of conflict, choice, and commitment. Free press.

Kahneman, D., Lovallo, D., \& Sibony, O. (2019, Spr). A Structured Approach to Strategic Decisions. Mit Sloan Management Review, 60(3), 66-73.

Kaufmann, L., Meschnig, G., \& Reimann, F. (2014, Jun). Rational and intuitive decision-making in sourcing teams: Effects on decision outcomes. Journal of Purchasing and Supply Management, 20(2), 104-112.

Keller, J., \& Sadler-Smith, E. (2019). Paradoxes and Dual Processes: A Review and Synthesis. International Journal of Management Reviews, 21(2), 162-184.

Khatri, N., \& Ng, H. A. (2000). The role of intuition in strategic decision making. Human relations, 53(1), 57-86.

Kickul, J., Gundry, L. K., Barbosa, S. D., \& Whitcanack, L. (2009, Mar). Intuition versus analysis? Testing differential models of cognitive style on entrepreneurial self-Efficacy and the new venture creation process. Entrepreneurship Theory and Practice, 33(2), 439-453.

Liu, J. S., \& Lu, L. Y. Y. (2012). An integrated approach for main path analysis: Development of the Hirsch index as an example. Journal of the American Society for Information Science and Technology, 63(3), 528-542.

March, J. G., \& Simon, H. A. (1958). Organizations. Wiley.

Matzler, K., Uzelac, B., \& Bauer, F. (2014, Sep). The Role of Intuition and Deliberation for Exploration and Exploitation Success. Creativity and Innovation Management, 23(3), 252-263.

McKenzie, J., Woolf, N., van Winkelen, C., \& Morgan, C. (2009). Cognition in strategic decision making: A model of non-conventional thinking capacities for complex situations. Management Decision, 47(2), 209-232.

Mikušková, E. B. (2017). Intuition in managers' decision-making: qualitative study. Journal for East European Management Studies, 22(3), 318-333.

Miller, C. C., \& Ireland, R. D. (2005, Feb). Intuition in strategic decision making: Friend or foe in the fast-paced 21(st) century? Academy of Management Executive, 19(1), 19-30.

Miller, D., \& Friesen, P. H. (1983). Strategy-making and environment: The third link. Strategic Management Journal, 4(3), 221-235.

Mintzberg, H., Raisinghani, D., \& Théorêt, A. (1976, June). The structure of "unstructured" decision processes. Administrative Science Quarterly, 21(2), 246-275.

Mintzberg, H., \& Waters, J. A. (1985, July - September). Of strategies, deliberate and emergent. Strategic Management Journal, 6(3), 257-272.

Mitchell, J. R., Friga, P. N., \& Mitchell, R. K. (2005, Nov). Untangling the intuition mess: Intuition as a construct in entrepreneurship research. Entrepreneurship Theory and Practice, 29(6), 653-679.

Mrvar, A., \& Batagelj, V. (2016, April 06). Analysis and visualization of large networks with program package Pajek. Complex Adaptive Systems Modeling, 4(1), 6.

Nonaka, I., \& Takeuchi, H. (1995). The knowledge-creating company: How Japanese companies create the dynamics of innovation. Oxford university press.

Okoli, J., \& Watt, J. (2018). Crisis decision-making: the overlap between intuitive and analytical strategies. Management Decision, 56(5), 1122-1134.

Reynolds, S. J. (2006, Jul). A neurocognitive model of the ethical decision-making process: Implications for study and practice. Journal of Applied Psychology, 91(4), 737-748.

Robinson, J., Sinclair, M., Tobias, J., \& Choi, E. (2017, Jul). More Dynamic Than You Think: Hidden Aspects of Decision-Making. Administrative Sciences, 7(3), 23.

Rossetto, D. E., Bernardes, R. C., Borini, F. M., \& Gattaz, C. C. (2018, June). Structure and evolution of innovation research in the last 60 years: review and future trends in the field of business through the citations and cocitations analysis. Scientometrics, 115(3), 1329-1363.

Sadler-Smith, E. (2004, Feb). Cognitive style and the management of small and medium-sized enterprises. Organization Studies, 25(2), 155-181.

Sadler-Smith, E. (2015, 2015/10/02). Wallas' Four-Stage Model of the Creative Process: More Than Meets the Eye? Creativity Research Journal, 27(4), 342-352.

Sadler-Smith, E. (2016a, Mar). The role of intuition in entrepreneurship and business venturing decisions. European Journal of Work and Organizational Psychology, 25(2), 212-225. 
Sadler-Smith, E. (2016b). 'What happens when you intuit?': Understanding human resource practitioners' subjective experience of intuition through a novel linguistic method. Human relations, 69(5), 1-25.

Sadler-Smith, E. (2019). Intuition in Management. In Oxford Research Encyclopedia of Business and Management.

Sadler-Smith, E., \& Hodgkinson, G. P. (2016, August). An analytic-intervention model of managerial intuition. Academy of Management Proceedings, 2016(1).

Sadler-Smith, E., Hodgkinson, G. P., \& Sinclair, M. (2008). A matter of feeling? The role of intuition in entrepreneurial decision-making and behavior. In W. J. Zerbe, C. E. J. Hartel, \& N. M. Ashkanasy (Eds.), Emotions, ethics and decision-making: Research on emotion in organizations (Vol. 4, pp. 35-55). Emerald Group Publishing Limited.

Sadler-Smith, E., \& Shefy, E. (2004, Nov). The intuitive executive: Understanding and applying 'gut feel' in decision-making. Academy of Management Executive, 18(4), 76-91.

Sadler-Smith, E., \& Shefy, E. (2007, Jun). Developing intuitive awareness in management education. Academy of Management Learning \& Education, 6(2), 186-205.

Salas, E., Rosen, M. A., \& DiazGranados, D. (2010, Jul). Expertise-based intuition and decision making in organizations. Journal of Management, 36(4), 941-973.

Sayegh, L., Anthony, W. P., \& Perrewé, P. L. (2004, June). Managerial decision-making under crisis: The role of emotion in an intuitive decision process. Human Resource Management Review, 14(2), 179-199.

Shane, S., \& Venkataraman, S. (2000). The promise of entrepreneurship as a field of research. Academy of management review, 25(1), 217-226.

Silva, J. T. M., Ablanedo-Rosas, J. H., \& Rossetto, D. E. (2019, August). A longitudinal literature network review of contributions made to the academy over the past 55 years of the IJPR. International Journal of Production Research, 57(15-16), 4627-4653.

Simon, H. A. (1955). A Behavioral Model of Rational Choice. The Quarterly Journal of Economics, 69(1), 99-118.

Simon, H. A. (1956, March). Rational choice and the structure of the environment. Psychological Review, 63(2), 129-138.

Sinclair, M. (2010, November). Misconceptions About Intuition. Psychological Inquiry, 21(4), 378-386.

Sinclair, M., \& Ashkanasy, N. M. (2005, Sep). Intuition: Myth or a decision-making tool? Management Learning, 36(3), 353-370.

Sinclair, M., Ashkanasy, N. M., \& Chattopadhyay, P. (2010, Jul). Affective antecedents of intuitive decision making. Journal of Management \& Organization, 16(3), 382-398.

Small, H. (1973, July-August ). Co-citation in the scientific literature: A new measure of the relationship between two documents. Journal of the American Society for Information Science, 24(4), 265-269.

Sonenshein, S. (2007, October). The role of construction, intuition, and justification in responding to ethical issues at work: The sensemaking-intuition model. Academy of management review, 32(4), 1022-1040.

Stanovich, K. E., \& West, R. F. (2000). Individual differences in reasoning: Implications for the rationality debate? Behavioral and Brain Sciences, 23(5), 645-665.

Taggart, W., \& Valenzi, E. (1990, Mar). Assessing rational and intuitive styles: a human information-processing metaphor. Journal of Management Studies, 27(2), 149-172.

Teece, D. J., Pisano, G., \& Shuen, A. (1997, Mach). Dynamic capabilities and strategic management. Strategic Management Journal, 18(7), 509-533.

Tranfield, D., Denyer, D., \& Smart, P. (2003). Towards a Methodology for Developing Evidence-Informed Management Knowledge by Means of Systematic Review. British Journal of Management, 14(3), $207-222$.

Tversky, A., \& Kahneman, D. (1974). Judgment under Uncertainty: Heuristics and Biases. Science, 185(4157), 1124-1131.

Van Eck, N. J., \& Waltman, L. (2010, Aug). Software survey: VOSviewer, a computer program for bibliometric mapping. Scientometrics, 84(2), 523-538.

Van Riel, A. C. R., \& Horváth, C. (2014). Conceptualizing intuition as a mental faculty: Toward a "critique of intuitive reason'and a process model of intuition. In S. Marta (Ed.), Handbook of research methods on intuition (pp. 42-56). Edward Elgar Publishing Limited.

Weaver, G. R., Reynolds, S. J., \& Brown, M. E. (2014, Jan). Moral Intuition: Connecting Current Knowledge to Future Organizational Research and Practice. Journal of Management, 40(1), 100-129.

Weick, K. E. (1995). Sensemaking in organizations (Vol. 3). Sage Publications, Inc.

Weick, K. E., \& Leite, D. M. (1973). A psicologia social da organização. Editora Edgard Blucher Ltda.

Zahra, S. A., \& George, G. (2002, April). Absorptive Capacity: A Review, Reconceptualization, and Extension. Academy of management review, 27(2), 185-203.

Zelikow, P., \& Allison, G. T. (1999). Essence of decision: explaining the Cuban Missile Crisis (Vol. 2). Longman.

Zhao, D., \& Strotmann, A. (2015). Analysis and visualization of citation networks. Synthesis lectures on information concepts, retrieval, and services, 7(1), 1-207. 